\title{
LIVING EXPERIENCE OF WOMEN WITH HIV/AIDS IN WEST JAVA INDONESIA
}

\author{
Ellya Susilowati \\ Polytechnic of Social Welfare, Bandung, Indonesia, ellyasusilowati1@gmail.com \\ Krisna Dewi \\ Polytechnic of Social Welfare, Bandung, Indonesia, krisna_dewi@ poltekesos.ac.id
}

\begin{abstract}
The purpose of this research is to understand how the experience of women's lives, so that it becomes the basis of social workers in providing help for women with HIV/AIDS. This research used a qualitative method with descriptive design to three women with HIV/AIDS who received services from the Komisi Penanggulangan AIDS/AIDS Prevention Commission in Kerawang Regency, West Java. Data collection techniques used were interviews, observation and documentation studies. The results of the research showed that women experienced changes after contracting HIV/AIDS from: 1) physical aspects experiencing changes in skin color, decreased health conditions; 2) in the psychological aspect it becomes more sensitive and quickly offended; 3) social aspects still experience discrimination from the family, and still cannot negotiate with their husbands regarding condom use; 4) economically, experiencing more expenditure for accessing to health services and purchasing drugs; 5) service aspects still have no partner counseling services and educational activities for the environment so there is still stigma and discrimination. The recommendation for the results of this research is that the Komisi Penanggulangan AIDS/AIDS Prevention Commission: 1) establish a counseling service program for couples; 2) improve support group programs for women; 3) counseling about HIV/AIDS in the family and community environment so as not to stigmatize and discriminate against women with HIV/AIDS.
\end{abstract}

Keywords: Experience, Life, Women, Living with HIV/AIDS 


\section{INTRODUCTION}

Women in a biological manner are vulnerable to contract HIV compared to men (Mason, 2010; Susilowati. E, 2013) and when they have contracted HIV, they are more quickly acquired into Syndrome Deficiency Syndrome (AIDS) (R. McIntosh, M. Rosselli 2012). But many women do not know and realize that they have contracted HIV from their partners, so they do not check themselves to find out their status. The number of HIV cases in women in Indonesia based on a report from the Ministry of Health in 2017 there were 17,579 women $(38 \%)$ who were positive for HIV, and as many as 2,959 women or $36 \%$ were positive for AIDS.

HIV transmission in women can be transmitted through heterosexuals, syringes and transmission from mother to child through breast milk. Heterosexual transmission to women includes through risk groups such as sex workers who contribute $3.4 \%$ of AIDS cases, while the general public such as housewives, private employees, and entrepreneurs contribute $40.3 \%$ of AIDS cases in Indonesia in 2016. This phenomenon is in line with data from the Ministry of Health in 2015 which showed that more than half $(50.3 \%)$ the forms of HIV transmission through sexual relations with heterosexual couples. It has an impact on the increasing number of AIDS cases in housewives. Meanwhile housewives are a group that most of them will become pregnant women and continue their descent.

The case of HIV/AIDS in pregnant women is also increasing and generally found in 20-29 years. In addition, HIV/AIDS in pregnant women causes more severe problems because it can endanger the life of the mother and transmit it to the baby through pregnancy, childbirth and breastfeeding. Transmission from mother to child also shows a significant increase. The Ministry of Health in 2017 reported 5,797 pregnant women who were HIV positive.

HIV/AIDS stands for Human Immunodeficiency Virus which can develop into AIDS or Acquired Immunideficeincy Syndrome if they don't get treatment. Once a person is infected with HIV, this virus cannot be eliminated. People will carry this virus throughout their lives and become carriers that can transmit it to others. The HIV virus attacks the immune system called CD4 cells ( $T$ cells) which help people to protect from infection. HIV destroys $T$ cells which results the individual is easy get an infection or cancer due to infection so that in the final stage of the development of the HIV virus is the appearance of symptoms of AIDS. The symptoms that are common in people with AIDS are: fever, sore throat, headache, muscle and joint pain, swollen lymph glands, fatigue, weight loss, night sweats for no apparent reason, the arise of skin rash and it symptoms occur repeatedly (Healthwise staff, 2017).

The HIV epidemic is not only a health problem, it also shows a complex and reciprocal relationship between the socio-political and biophysical dimensions of human health (King, Brian Winchester, Margaret S. 2018. 64- 
71). The social dimension that occurs as the second epidemic is the emergence of stigma, and discrimination faced by sufferers of HIV/AIDS. The second epidemic shapes the lives of ODHA, their social environment, the types of services received, the attitudes and treatment from service providers. ODHA also face social isolation, barriers to relationships with their families and sexual relations with their partners, lack of needed services, loss of jobs, loss of social security, loss of income, separation from family and friends.

The impact of the HIV/AIDS epidemic for women is heavier than men. For example, stigmatizing women with HIV-positive status, they are often blamed that considered to bring the disease to sexual relations with their partners (Cuca, Y. P. 2013).

Women also have to bear the heavy burden of the HIV/AIDS epidemic according to their roles both as mothers, as wives and as household heads (Cherry, S., deMarrais, K., Keita, C., Davis, M., \& Lee, J, 2018). The burden of women with HIV/AIDS must also bear the burden and responsibility for the continuity of their household. On the other hand, women are also people who are expected to do homework, care for sick family members, while helping husbands to make living for family life, especially for husbands who are sick and die due to HIV/AIDS (Susilowati.E, 2013).

HIV/AIDS also has an impact on the psychosocial conditions of women in dealing with HIV/AIDS. Stress the most dominant faced by women is perceived stress and HIV symptoms. Perceived stress related to appraisal contracting of HIV/AIDS, the chronic burden is related to negative behavior due to stress, a major event when seeing the closest person die suddenly cause of HIV, and interpersonal related to efforts to build relationships with friends after contracting HIV (R. McIntosh and M. Rosselli. 2012).

Cherry, S., deMarrais, K., Keita, C., Davis, M., \& Lee, J (2018) conducted a research to explore how AfricanAmerican women who have been infected with HIV for 10 years or more as People with HIV/AID. Women share experiences of growing up with family, initial difficulties, turning points in their lives leading to and following their HIV diagnosis, and the ways they make meaning from their diagnosis. The results of this research indicate that there are similarities in women's stories, including the way HIV is infected, the challenges faced, how their efforts create new life. Women also tell how to navigate difficult experiences such as neglect, pregnancy, and loss of loved ones. For some women, difficult experiences are the gateway to drug abuse. But there are experiences about how they first responded to diagnosis and treatment, and reached the point where they decided to take an active role in leading a healthy life, regardless of their diagnosis. From this situation shows that women have various life experiences when facing HIV/AIDS.

These situations need to be understood by Social Workers who work in the field of HIV, especially those dealing with women with HIV/AIDS. Interventions for HIV/AIDS social work, 
especially for women, are unlikely to succeed without regard to the life context of women with HIV/AIDS.

To provide effective services, social workers can develop intervention strategies based on life experiences of those who have contracted HIV/AIDS including women with HIV/AIDS. They have had experiences related to their illness. The experience is related to: (1) physical suffering that affects his physical functioning, (2) his psychological life due to concerns, anxiety that the disease cannot be cured and can be transmitted to others, and (3) his social life is mainly related to stigma and discrimination from the closest social environment as well as society in general.

This experience can provide important information relating to physical, psychological, social, economic aspects and in the access needed by women with HIV/AIDS to social workers to design relief strategies according to their needs. Some results of the research suggest that women have different experiences with men in the face of HIV/AIDS (Ship \& Norton, 2000; Mason in Poindexter, 2010, Susilowati. E, 2013).

This difference is seen in terms of physical, psychological and social between women and men. Physically or biologically, women are twice easily infected with HIV compare with men (Aditya, 2005; CDC 2008; Mason in Poindexter 2010; R. McIntosh, M. Rosselli. 2012). Every biography of a woman's life experiences is different from one another. Women's vulnerability can come from a combination of biological factors and gender inequality (Standway, 2008, Ciambrone; 2003; WHO, 2009 in Susilowati. E, 2013).

Experience is something that cannot be separated from human life, human get learning and guidelines to render the reaction to the situation they face through experience.

Health Office of the West Java Province reports the number of HIV cases in West Java in 2018 reached 37,485 cases while AIDS reached 10370 cases. The most significant increase in HIV and AIDS cases is experienced by households (West Java Health Office, 2018). Kerawang Regency is one of the regencies in West Java Province with a high number of HIV cases. The number of AIDS cases reported by KPA Kerawang Regency in 2017 amounted to 841 cases that spread across 15 subdistricts. The number of AIDS cases in women is $29 \%$. While the number of men is $71 \%$, and most of them already have a partner, namely women, so the possibility of the number of women infected with HIV/AIDS will increase. However, this number cannot be ascertained because many women have not tested HIV and have not participated in programs for HIV prevention in the HIV service institution. The limited number of women in HIV services is also related to the issue of stigma and discrimination.

Based on this background, the researchers were interested in conducting research on the life experiences of women with HIV/AIDS in Kerawang Regency. This research focused on: 1) experience from the physical aspect; 2) experience from the 
psychological aspect; 3) experience from the social aspect; 4) experience from the economic aspect; and 5) experience in accessing services needed.

\section{METHOD}

\section{Research Design}

This research used a qualitative approach with descriptive methods to get a factual and accurate description about the life experiences of women with HIV (Creswell, 2013). The research was conducted in the Komisi Penanggulangan AIDS Daerah/Regional AIDS Prevention Commission (KPAD) West Java which has assisted people with HIV/AIDS including women.

\section{Determination of informants}

Determination of informants was done in a purposive manner, which was to determine the informants with criteria that had been exposed to HIV for more than two years, to be guided by KPAD and willing to become informants in this research. Based on these characteristics, the informants who could be encountered only three women with HIV/AIDS, namely: 1) $\mathrm{Hr}$ (31 years old) with married status and formerly sex workers; 2) Sm (30 years old) housewife and married status; 3) Am (24 years old) married status and as a housewife.

\section{Data Collection Techniques}

Data collection was carried out by interview, observation and documentation study techniques. Interviews were conducted with each informant in a place that was considered comfortable so that women could explain their experiences. Researchers conduct interviews with non-judgmental attitudes and accept informants as they are. This attitude to make easier the interview process.

Before the research process is carried out, the researcher explains the purpose of the research and the research process. For voluntary willingness, informants signed an informed consent sheet. Observations were made to look at the physical and health conditions and the expression of the informants when sharing their experiences. Documentation studies were conducted to obtain data on the health history of informants and services at KPAD institutions in Kerawang Regency.

\section{Data Analysis Techniques}

Data analysis was carried out by credibility testing by extension of observation, increasing persistence, triangulation that is by interviewing KPAD officers, and using reference materials, member checking to find out how far the data was obtained according to the data giver, and confirmability testing that is research result test which related to the carried out process. Data analysis techniques are carried out during the research, which is before entering the field, while in the field, and after completion in the field. Analysis after entering the field is carried out at the time of data collection and after completion of data collection in a certain period. The research process was carried out for eight 
months from March to November 2018.

\section{RESEARCH RESULT}

This research describes in depth about the experience of ODHA women living from various life backgrounds, namely the history of HIV transmission, experience related to physical, psychological, social relations, and the use of services after becoming people with HIV/AIDS. Understanding the experience of ODHA is very important for professions that provide services to them to help them achieve a quality life and reduce transmission caused by incomprehension of both ODHA themselves and those who interact with ODHA.

\section{Background of women life with HIV/AIDS}

The background of the informant's life in the research is different, namely:

a. Work as a karaoke guide. Informant $\mathrm{Hr}$ (31 years old) has a background working as a karaoke guide and sex worker in Ancol Jakarta and changing sex partners.

b. Ever been married to a driver who often goes out of town. Sm informant (24 years old) as a housewife married to the first husband who had a job as a freight driver out of town and had high mobility. The first husband and first child died due to AIDS.

c. Injection Drug Users (IDUs) and married IDUs have also been sex workers. Informant
Am (30 years old) is a former injecting drug user (Injection Drug Users - IDU) and married the first husband of an IDUs. The first husband and first child died due to AIDS. After the husband died, working as a sex worker, and currently works as an HIV activist.

These three informants were all left by their husbands to die cause of HIV/AIDS, and they learned that they had contracted HIV after being abandoned by their first husband. When this research was conducted, all of them had remarried with men who were not HIV positive. When asked about whether her husband had taken an HIV test, they all answered that her new husband had not taken an HIV test. The reason is that they do not inform and encourage their husbands to test for HIV. One informant among them did not even open her HIV positive status to her husband.

\section{The Aspects of ODHA Women's Experience}

a. History of HIV Transmission

An overview of the history of HIV transmission experienced by informants included the experience of being exposed to HIV, the way the informant first found out he was exposed to HIV, and the process of transmitting HIV to informants.

1) Indications of exposure to HIV. All informants explained that their initial experience of knowing that 
they were exposed to HIV was indicated by: (a) Skin diseases such as itching, skin becoming black; (b) Continuous diarrhea and mouth sores until the lips are damaged; and (c) feeling weak and unable to get up.

2) Knowing that he is exposed to HIV: All informants explained that the way they found out that they were suffering from HIV was through the results of an HIV test offered by health workers when they were treated. The reaction at that time they explained fear and shocked.

3) The way of transmit HIV to ODHA women is through: a) Heterosexual, is from husband and one person changing partners: b) Syringes and heterosexuals. One informant said that he was exposed to HIV from a syringe and was also heterosexual with her husband who was also an IDUs; c) Transmission to children. Two informants were found also transmitting HIV to their children, and their children died from contracting HIV.

\section{b. Physical Experience}

Changes in women after being exposed to HIV have experience of changing physical conditions. Physical changes experienced are: (1) experiencing recurrent diseases such as continuous diarrhea and mouth sores /ulcer in the mouth; (2) languid increase and getting sick easily; (3) change in skin color becomes whiter or increasingly pale (expressed by two information); and 4) his skin becomes scaly thick and feel itchy (experienced by one informant).

To overcome the physical condition, women with HIV/AIDS have also experienced coping with physical problems that their suffered with the following way: 1) going to health services such as to the public health center or hospital using BPJS. One informant said that he had been treated routinely every month at the Karawang Hospital, especially in the Special Polyclinic for HIV services to get ARVs and vitamins; and 2) using herbal medicine. One informant suggested that in addition to medical treatment, also using herbal medicines.

\section{c. Psychological experience}

All informants said that the illness which their suffered is a scary disease that led to death. They have experience in how the psychological situation in an initial exposed and after exposure of HIV.

1) The initial psychological experience of exposure to HIV/AIDS was presented by two informants a) feeling confronted with 
something scary", because they considered that this disease had not been cured and was contagious and deadly; b) "confused and shocked" said by one informant who only worked as a housewife. She feels that she never performs something that involving risk.

(2) The psychological experience after being exposed to HIV/AIDS is: (a) fear of facing death; another informant is afraid to be shunned and insulted by people around him because his illness is considered dirty; (b) feel the most suffering; and (c) irritability and sensitivity. For that, one informant suggested that to overcome the psychological problem are the importance of support, especially from the family.

\section{d. Experience from the social aspect}

The experience of women with HIV/AIDS from the social aspect includes the experience of relationships with partners, relations with family and relations with the local environment.

\section{1) Relationship with partner.}

The spouse of all informants at the time of this research were the second husband. Relationships with partners related to sexual relations and acceptance of the second husband. All informants stated that they did not use condoms when having sex with their husbands, while their second husbands were not HIV-positive status. All informants also said that they did not try to influence her husband to use condoms by reason of maintaining a relationship as husband and wife to not cause anger from the husband. While one informant stated that there was a fear of being abandoned by her husband. However, two informants opened their HIV-positive status to their second husbands, and the husband accepted it. Husbands receive the status of their wives infected with HIV positive, this is because their husbands lack of understanding about HIV. They assume that HIV is an ordinary disease that can be treated. While one other informant did not open his HIV positive status to his partner because he felt innocent of contracting HIV.

2) Relationship with family. Relationship with family is a relationship between informants and their families, namely parents or siblings. This relationship with the family begins with opening status to the family and its influence on relations with family or parents. Two 
informants suggested opening status with their close family, namely their parents. The response from the family when they found out about HIV-positive of informants was quite painful and they also discriminated by separating their eating utensils. This was also stated by informants from KPAD officers that there were still many families who did not know clearly about HIV disease so that when there was one family member who was HIV, the family discriminated and even left people with HIV/AIDS alone, so HIV/AIDS sufferers became neglected. However, there was the experience from one informant who had a residence different from the city where his parents and family lived so he did not disclose his status to his extended family. Regarding the family status of people with HIV/AIDS, the informant from the KPAD also stated that when there was a family member who was HIV, the family, besides discriminating, even left ODHA alone, so that ODHA became neglected. This is also caused by limited family knowledge about HIV/AIDS

3) Relationship with friends. Relationships with friends when their friends knew that informant infected HIVpositive are as follows: (a) initially shunned by friends. Two informants explained that they had the experience of being shunned by their friends when they found out about HIV positive. His friends often whispered so that make informants uncomfortable; b) gradually friend accepted. Two informants continued to get along with their friends even though they were initially shunned, so that their friends gradually accustomed to it conditions.

4) Experience relationships with neighbors. All informants explained that in general the neighbors knew that the informant was exposed to HIV from one of his friends or family members who told him about the situation so that information about the informant as an HIV sufferer spread to his neighbor's environment. Initially people he knew kept away from informants for fear of being infected, but now his neighbors accepted him as before. The information conveyed by informants about the experience of relations with their neighbors was also reinforced by the explanation of informant AW 
as KPAD staff that many people still viewed HIV as a dangerous and contagious disease so that people tended to discriminate against sufferers.

5) Relationship experience with service personnel. All informants stated that the health care workers where they were treated were good, they treated the informants in a cordially and friendly manner and always reminded them to routinely consult and seek treatment so that their health was maintained. This indicates that health care workers have understood their responsibilities in serving patients including HIV patients. This is also inseparable from the role of KPAD as a regional institution that specializes in dealing with HIV/AIDS.

\section{e. Experience from the economic aspect}

This economic experience is related to the economic burden after they become People with HIV/AIDS. All informants stated that the economic burden has increased with regard to increasing vitamin needs, nutritious food and milk specifically for children who are HIV/AIDS positive and transport for treatment. Meanwhile, two informants who usually work with quite large incomes (i.e becoming sex workers and karaoke guides), currently they do not work with sufficient income. Economic conditions only rely on the income of husbands who work as laborers.

\section{f. Service access experience}

The services needed for people with HIV/AIDS are: 1) Health services that can help them to maintain their health conditions, because as people with HIV/AIDS must routinely to consume of Antiretroviral (ARV) to maintain their immune system. According to the informants after they joined with the KPAD, they had easy access to health services and did not need a lot of money because they all already had health insurance (BPJS); 2) HIV/AIDS Institution services such as KPAD Kerawang Regency become important for women with HIV/AIDS. All informants get special services to meet the needs of people with HIV/AIDS such as peer support groups, condom supplies, vitamins and information about services that can be utilized such as skills training for productive economic activities. In addition, the informants can also attend regular meetings held by KPAD, where those in the meeting were filled with spiritual formation, sharing experiences and recreational activities. 


\section{DISCUSSION}

Based on the research findings on the third experience of women informants with HIV/AIDS, this can be discussed below:

1. HIV Transmission in Women. The research results showed that women exposed to HIV in heterosexual manner were not those who had a risky background in life such as a companion to karaoke (plus), sex workers or injecting drug users, but also as housewives who only stayed at home. This proves that the rate of increase in transmission to housewives is increasing, as reported by the AIDS Prevention Commission. The transmission route through injecting drug use and social contact with drug users also occurs in one informant, this indicates that women are more likely to contract HIV than men who have partners infected with HIV (Capmbell, 1999). The experience of women with HIV is related to HIV transmission as follows:

a. Too late to find out about being exposed to HIV. In this research indicated that all informants were late knowing about exposure to HIV/AIDS. This is due to limited knowledge of HIV about HIV symptoms and the risk of transmission. This also causes transmission to his child. Their experience, in addition to her husband died, two informants lost their first child due to HIV. b. Become a source of HIV transmission in new partners. All informants in this research continued their lives by remarrying husbands who were not yet HIV. In fact, one informant did not disclose his status as a woman with HIV. Even though they already know about HIV transmission but they don't want to follow HIV prevention rules such as using condoms when having sex with their husbands, this is due to their fear of being abandoned by their husbands. While new husbands also have limitations about HIV transmission, they know that HIV is a kind of common disease. This condition is the situation of the wife's transmission route to her partner.

c. Transmission to children. Women in this research had experience with HIV transmission to their children. In addition to having lost a child due to HIV, during pregnancy they did not take part in the program of transmission prevention from mother-to-child (Prevention Transmition Mother to ChildrenPMTCT).

\section{Maintenance of physical health}

Women after being HIV positive experience physical changes, especially related to the decline in health conditions. This condition of physical change will worsen if women do not understand about 
health care (J. Thompson, Y. Havenga, S Naude.2015). However, the results of the research show that women with HIV have made efforts to address health problems with access to health services. One person who experiences anemia because lack of intake and vitamins, due to economic problems. Economic conditions also affect health care for women with HIV/AIDS, because women must regulate household income for personal expenses and household needs (B. King, M. Winchester, 2018) while their income is limited.

Changes in physical conditions are also affected by the effects of consuming ARVs. The use of ARVs that are inappropriate and obedient will affect the decline in health conditions (E. L. Machtinger et all. 2012), this was felt by one informant who felt the effects of disobedient of ARVs became susceptible to skin fungus, continuous flu. It is important for women with HIV to always update their knowledge (J. Thompson, Y. Havenga, S Naude.2015).

The research results also showed that all informants did not use condoms when having sex with their husbands. This condition will also have an impact on the health of women with HIV/AIDS. This condition also relates to cultural issues related to status as a wife, where the wife must follow the husband's wishes. Women with HIV/AID still have not dared to 'negotiate' to optimize their health.

\section{Psychological conditions}

The results of the research showed that women had psychological experience, especially at the beginning of knowing exposure to HIV. Anxiety and fear of death were experienced by all informants. Anxiety in this initial condition is related to the process of receiving status of HIV-positive and recalling the closest person who died like his first husband and child (Mcintosh, R. C., \& Rosselli, M. 2012).

Besides that, fear is related to interpsersonal relationships with current partners and discrimination with families. This condition if allowed has the potential to encourage the progression of HIV infection to AIDS.

Psychosocial disorders can affect the central nervous system with the immune system that continues toward the journey of HIV infection to AIDS (Nasronudin, 2007; R. McIntosh, M. Rosselli. 2012; Machtinger, E.L, Haberer, J.E, Wilson, T.C, \& Weiss, D.S, 2012).

Social support from family or closest people becomes important for people who are new to their status of HIV positive. If they are ready to open their positive status to the closest person, assistance from social workers is needed.

\section{Experience in Social Life}

Experience in social life is related to social relations with spouses, families, neighbors and good friends in their environment 
whether friends in the work environment or social intercourse friends. The results of the research show that there are still issues of stigma and discrimination. Such discrimination is obtained from the closest family. The form of discrimination is by keeping tableware away. The experience of one informant made the reason for another informant not to open the status of HIV positive to families who coincidentally living far away. "......yet, I perform my life anyway," said one of the informants. Stigma is still an issue that was feared by one informant, this reason also make one informant did not open status of her HIV-positive with his second husband. She also did not try to explain what HIV is. However, one

\section{Economic Life}

The economic risk that experienced by women with HIV is an increase in spending on health in addition to household expenditure. While income is limited compared to when the women still work. Two informants have worked but their jobs are at risk for the spread of HIV. B. King, M. Winchester (2018) suggests that households from HIV positive families face livelihood and health challenges. On the other hand, spending on health needs is increases, but people with HIV positive cannot work full time due to health conditions. The research results showed that there was one female informant working part time offering medicines with a multi-level informant who has a background in injecting drug users and formerly sex workers, stated that the stigma experienced by a person is not only due to HIV status but more complicated by issues related to the acceptance of it person toward the HIV status that must be undergone as a wife of injecting drugs user's or formerly sex workers.

The results of this research also show that family and community knowledge is still limited about HIV, so that families as sources who are expected to provide social support actually provide stigma and discrimination. The HIV epidemic as an epidemic of stigma and discrimination requires efforts so that women with HIV can run their lives healthy.

marketing system, but the income were very minimal. While the other two informants were very hopeful of supporting job training and productive economic assistance from the government as venture capital.

On the other side of the economic aspect, women with HIV sometimes experience a dilemma to prioritize expenditures between children's needs, their household and their health. Sometimes women ignore their needs, they are more concerned with the needs of their children. This condition makes it difficult for women with HIV to achieve a good quality of life. 


\section{Access services for women with HIV}

Health services are the most needed service besides social services. The research results showed that women with HIV had access to health services, even all informants already had health insurance. But the problem is the limited of transportation to go to health services, this condition can impede the women with HIV from getting health checks and getting ARVs. Other services most needed are psychosocial services. All informants said that they really benefited from access to the Komisi Penanganan AIDS Daerah (KPAD) as a service institution for people with HIV/AIDS. Informants get services about information, social support and assistance with access to services. So that when they have problems, especially related to health and psychosocial, they can come to the institution. By coming to the institution they also feel that they are not alone, but they have a community to share with each other. But at this institution there is no service to couples. While women with HIV/AIDS who are become informants are at risk for HIV transmission with their partners. Their partners also don't understand about HIV. They are less open when they come to service institutions.

\section{CONCLUSION}

Women after having status of HIV positive have changes in both physical, psychological, social and economic conditions. Physical conditions are related to the decline in women's health conditions, psychosocially women also face anxiety related to changes in life and illness. On the other hand women with HIV still face the issue of stigma and discrimination toward the people who closest to them. Women also face economic problems to meet the need to stay healthy, while the condition of women is no longer productive. Service institutions for women with HIV become indispensable resource for the survival of women with HIV/AIDS. The living experience of ODHA women is expected to be the basis for improving service programs for women with HIV/AIDS.

\section{REFERENCES}

Alleyne, B., \& Gaston, G. (2010). Gender disparity and HIV risk among young black women in college. Affilia Journal of Women and Social Work. 25 (2), 135- 145.

Aral, S. O., \& Wesserheit, J.N. (1995). Interactions among HIV, other sexually transmitted diseases, socio economic status, and poverty in women. In A. O'Leary \& L.S. Jemmott (Eds), Women at risk: Issues in the primary prevention of AIDS, 13-42

Brinkhoft, MWG \& Boule, A., Weigel, R, Marthers, C. (2009). Mortality of HIV - infected patient starting antireroviral therapy in sub Sahara Africa: comparison with HIV- 
unrelated mortality, Plos Med, 6 (4): 1371

B. King, M. Winchester (2018). HIV as social and ecological experience. Social Science and Medicine. Vol.208.Issue: March.Pages: 6471. Journal homepage: www.elsevier.com/locate/socscim ed HIV

Cambell, C. (2002). Women, families, and HIV/AIDS: a sociological perspective on the epidemic in America. Cambridge: Cambridge University Press

Catherine, K, M. (2009). Beyond routine HIV testing: beliefs, perceptions, and experiences of low income women of color. Journal of HIV/AIDS \& Social Service, (9), $219-237$.

Chang, Ester, \& Johnson, Amanda. 2018. Living with chronic illnes and disability: principle for nursing practice. 3 nd ed. Australia: Elsevier Australia.

Cuca, Y. P. (2013). Women living with HIV: Social stigma and reproductive decisions (Order No. 3587871). Available from Sociology Database. (1427345226). Retrieved from https://search.proquest.com/docvi ew/1427345226? accountid $=50790$

Cherry, S., deMarrais, K., Keita, C., Davis, M., \& Lee, J. (2018). "My determination is to live": Narratives of african-american women who have lived with HIV for 10 or more years. The Qualitative Report, 23(10), 24902510. Retrieved from https://search.proquest.com/docvi ew/2184344444? accountid=50790

Creswell, John W. 2013. Oualitative Inquiry \& Research Design. California: Sage Publications.

C. Logie, Y Wang, ALacombe-Dunca et al. (2017). HIV-related stigma, racial discrimination, and gender discrimination: Pathways to physical and mental health-related quality of life among a national cohort of women living with HIV Carmen. Journal Preventive Medicine. Vol: 107. July 2017. Pages.

36-44. www.elsevier.com/locate/ypmed.

Dirjen Pengendalian dan Pencegahan Penyakit. 2017. Laporan Perkembangan HIV/AIDs dan Penyakit Infeksi Menular Seksual (PIMS) Triwulan I Tahun 2017. Kementerian Kesehatan RI.

E. L. Machtinger, J. E. Haberer, T. C. Wilson D, S. Weiss (2012). Recent trauma is associated with antiretroviral failure and HIV transmission risk behavior among HIV-positive women and femaleidentified transgenders.

Granich, R. \& Jonathan, M. (2003). Ancaman HIV dan kesihatan masyarakat. Yogyakarta: Insist Press.

Healthwise staff. 2017. HIV (Human Immunodeficiency Virus) Infection. Michigan: Healthwise, Incorporated.

Thompson, Y. Havenga, S Naude (2015). The health literacy needs of women living with HIV/AIDS. Health SA Gesondheid. Jornal. Vol.20. issue 1. Pages. 11-21 
Journal

homepage:

http://ees.elsevier.com/hsag/defau

lt.asp.

Karawang

Info.

2008.

www.karawanginfo.com.

Komisi Penanggulan AIDS. 2016. https://www.kompasiana.com

Machtinger, E. L., Haberer, J. E., Wilson, T. C., \& Weiss, D. S. (2012). Recent trauma is associated with antiretroviral failure and HIV transmission risk behavior among HIV-positive women and female-identified transgenders. AIDS and Behavior, 16(8),

2160-70.

doi:http://dx.doi.org/10.1007/s104 61-012-0158-5

Mcintosh, R. C., \& Rosselli, M. (2012). Stress and coping in women living with HIV: A meta-analytic review. AIDS and Behavior, 16(8), 214459.

doi:http://dx.doi.org/10.1007/s 104 61-012-0166-5

Michele Angela Rountree \& Meredith Mulraney. (2010). HIV/AIDS Risk Reduction Intervention for Women who have Experienced Intimate Partner Violence. Clinical Social work Journal.Vol: 38. Issue: 2. Page.207-216. DOI.10.1007/s10615-008-0183-z.

Notoatmodjo, S. (2005) Metode Penelitian Kesehatan, edisi revisi, Rineke Cipta. Jakarta.

Poindexter, Chynthia Canon. 2010. Handbook of HIV and social work: principle, practice, and population. New Jersey: John Wiley \& Soni, Inc.
Susilowati, E. (2013). Wanita yang mempunyai HIV/AIDS dan pasangan suami yang menyuntik dadah di Bandung, Indonesia (Doctoral dissertation, Universiti Sains Malaysia)

Rountree, M. A., \& Mulraney, M. (2010). HIV/AIDS risk reduction intervention for women who have experienced intimate partner violence. Clinical Social Work Journal, 38(2), 207-216. doi:http://dx.doi.org/10.1007/s106 15-008-0183-z

Turan, J. M., Bukusi, E. A., Onono, M., Holzemer, W. L., Miller, S., \& Cohen, C. R. (2011). HIV/AIDS stigma and refusal of HIV testing among pregnant women in rural Kenya: Results from the MAMAS study. AIDS and Behavior, 15(6), 1111-20. doi:http://dx.doi.org/10.1007/s104 61-010-9798-5. 